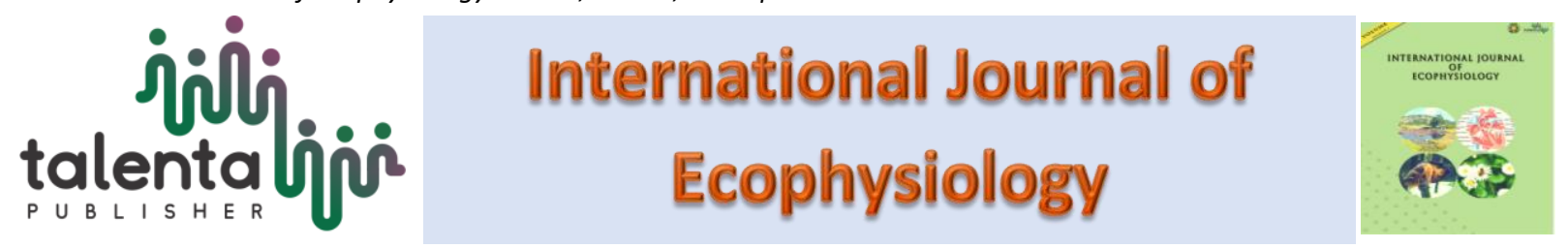

\title{
The Potential of Guava Leaf Extract as A Natural Preservation for Fish
}

\author{
Riyanto, $^{1 *}$, Sartini $^{1}$, Rika Hardani Sitorus ${ }^{1}$ \\ Department of Biology, Universitas Medan Area, Medan, North Sumatra, Indonesia, Jln. Kolam no.1 \\ Medan, North Sumatera 20223.
}

\begin{abstract}
Fish is kinds of food that easy to spoil. High protein content in fish makes the food is a good medium for microorganisms. People commonly buy fish for consumption, however, not all fish are consumed at the same time. Fishes were stored in freezer for several days or preserved with additional chemical preservation. The use of organic preservatives have no harm. This paper discussed guava (Psidium guajava L) leave as natural fish preservation. The objectives were to analyze the potency of the leaves as a natural preservation for mackerel fish (Rastrelliger sp.). Fime parameters used to determine the fish quality as follows : gills, eye, texture, odour and mucilage. The treatments were leaf methanolic extract with doses 0, 20, 40,60 and 80\%. Data were taken on from 1 to 5 days after storage. The results showed that (i) Fish quality was decline and start to depraved at 2 day storage, especially at control treatment ( $0 \%$ extract). Treatment at doses 60 and $80 \%$, the fish quality were still relatively good over 3 days storage. Even though the fish samples have been starting spoilage, those fishes were still available to be consumed. At the same time, with the other treatment, the fish samples have been spoiled and no more available to be consumed. However, at 5th day of storage, all samples at all treatments were spoiled. Overall results, it can be concluded that extract of guava leaves can be has as fish preservative.
\end{abstract}

Keyword: dosage, extract, guava leaves, mackerel fish

Received 8 November 2019 | Revised 25 December2019 | Accepted 26 January2020

\section{Introduction}

Consumption of fish as a protein sorrce is increasing continually in relation with increasing human population. Fish expansion in consumption has been driven by increased production, reduced wastage, better utilization, improved distribution channels and growing demand, linked with population growth [1]. Fish will be easy spoil because fish body is a good media for growth of bacteria and other microorganisms [2]. People buy fish for consumption but not all fish are consumed at the same day. Usually, fishes, particularly sea fishes are storage for several days with additional ace or chemical substances for preservation. Additioan chemical

\footnotetext{
*Corresponding author at: Department of Biology, Universitas Medan Area, Medan, North Sumatra, Indonesia, Jln. Kolam no.1 Medan, North Sumatera 20223

E-mail address: riyanto_99@yahoo.com
} 
preservation such as salt change the taste. Cahyono [3] mentioned the use of natural preservations such as bay-leaves (Syzygium polyanthum), betle leaves (Piper betle) and orange extraction.

This paper examine guava leave (Psidium guajava) as natural for fish preservation. Psidium guajava has been used in traditional medicine in many cultures throughout Central America, the Caribbean, Africa, and Asia [4]. People uses common guava for food and herbal. There are estimated, more than 150 species of guava in the world [5]. According to Rattanachaikunsopon et al, [6], the leaves of P. guajava contain the flavonol morin, morin-3-O-lyxoside, morin-3-Oarabinoside, quercetin and quercetin-3-O-arabinoside. Heuzé et al, [7] mentioned that guava was an edible fruit and can be eaten raw or cooked. The processing of the fruits yields byproducts that can be fed to livestock. It is very useful to our health. The leaves can also be used as fodder. According to Sudarsono et al. [8] common guava leaf contains flavonoid, tannin $(17.4 \%)$, fenolic $(575.3 \mathrm{mg} / \mathrm{g})$ and eteris oil.

One of fish species that is commonly consumed is mackerel fish. The fish is an important that is consumed worldwide. According to FAO Fact Sheet [9] the mackerel fish have deeply forked tails and are smaller and slimmer than tuna. The mackerel is spoils rapidly, especially in the tropics. Traditional commonly used to preservee fish include drying, salting, pickling and smoking. Modern techniques also used such as of freezing and canning those have taken on a large importance [10]. Croker et al. [11] explained that mackerel is an important food fish that is consumed worldwide since hundred years ago. Many fisheries were traditionally pickled mackerel with large amounts of salt, which allowed it to be sold widely. The purpose of this study was to analyze guava (Psidium guajava $\mathrm{L}$.) leaves as a fish natural preservation.

\section{Materials and Methods}

This experiment used 2 factors, guava leaf methanolic extract with doses: $\mathrm{K} 0=0 \%, \mathrm{~K} 20=$ $20 \%, \mathrm{~K} 40=40 \%, \mathrm{~K} 60=60 \%, \mathrm{~K} 80=80 \%$ and time of storage $(\mathrm{H})$ from 1 day $(\mathrm{H} .1), 2$ days (H.2), 3 days (H.3), 4 days (H.4) and 5 days (H.\%)

Treatment combinations are as follow:

$\begin{array}{lllll}\text { K0-H.1 } & \text { K20-H.1 } & \text { K40-H.1 } & \text { K60-H.1 } & \text { K80-H.1 } \\ \text { K0-H.2 } & \text { K20-H.2 } & \text { K40-H.2 } & \text { K60-H.2 } & \text { K80-H.2 } \\ \text { K0-H.3 } & \text { K20-H.3 } & \text { K40-H.3 } & \text { K60-H.3 } & \text { K80-H.3 } \\ \text { K0-H.4 } & \text { K20-H.4 } & \text { K40-H.4 } & \text { K60-H.4 } & \text { K80-H.4 } \\ \text { K0-H.5 } & \text { K20-H.5 } & \text { K40-H.5 } & \text { K60-H.5 } & \text { K80-H.5 }\end{array}$

The working procedure was as follow: preparation of common guava leaf methanolic extract. Preparation of fresh mackerel. Fish preservation treated by the leaf extract was monitored their quality from day 1 , day 2 until day 5. Quality of the fiah was scored from 1 (low/poor quality) 
until 9 (high/good quality) via physical condition using score-sheet. The score were as follow: Score $(1-9)$ and physical criteria of fish quality.

\begin{tabular}{|c|c|c|}
\hline Fish parameter & Criteria and specific quality & Score \\
\hline Eye & $\begin{array}{l}\text { - } \quad \text { Bright eye, stick-out pupils, white cornea. } \\
\text { - Slightly bright eye, slightly brown pupil, white cornea } \\
\text { - } \quad \text { Concave eye, browned pupil, turbid cornea. } \\
\text { - } \quad \text { Very concave pupil, yellow cornea }\end{array}$ & $\begin{array}{l}9 \\
6 \\
3 \\
1\end{array}$ \\
\hline Gills & $\begin{array}{l}\text { - } \quad \text { Red color sharply, no mucous } \\
\text { - Slightly red color, no mucous. } \\
\text { - } \quad \text { Red -brown color with thin mucous. } \\
\text { - White brown color with tick mucous }\end{array}$ & $\begin{array}{l}9 \\
6 \\
3 \\
1\end{array}$ \\
\hline Aroma & $\begin{array}{l}\text { - } \text { Specific fresh aroma. } \\
\text { - } \quad \text { Amutral aroma. } \\
\text { - } \quad \text { Strong ammonia and acid aroma } \\
\text { - }\end{array}$ & $\begin{array}{l}9 \\
6 \\
3 \\
1\end{array}$ \\
\hline Texture & $\begin{array}{l}\text { - } \quad \text { Compact but elastic. } \\
\text { - Slightly compact, slightly elastic } \\
\text { - } \quad \text { Little bit soft } \\
\text { - } \quad \text { Very soft }\end{array}$ & $\begin{array}{l}9 \\
6 \\
3 \\
1\end{array}$ \\
\hline $\begin{array}{l}\text { Mucilage at } \\
\text { body surface }\end{array}$ & $\begin{array}{l}\text { - } \text { Bright, thin layer mucosa } \\
\text { - Mucosa began to muddy with white color } \\
\text { - Thick mucosa with white brown color } \\
\text { - } \text { Mucosa will be thick with yellow-brown color }\end{array}$ & $\begin{array}{l}9 \\
6 \\
3 \\
1\end{array}$ \\
\hline
\end{tabular}

\section{Result and Discussion}

The results, scoring of physical fish quality from observation of 5 parameter in which each parameter in 1 replicates were shown in Table 1. The range of score is from 9 (high/good quality) to 1 (low/poor quality).

Table 1. Summary Score data observation of 5 parameters

\begin{tabular}{cccccccc}
\hline \multirow{2}{*}{ No } & Concentration & Days of & & \multicolumn{5}{c}{ Average score (from 4 replicates) } \\
\cline { 5 - 8 } & of leaf extract & storage & Eye & Gills & Aroma & Texture & Mucilage \\
\hline 1 & K0 & H.1 & 9 & 9 & 9 & 9 & 9 \\
2 & K0 & H.2 & 6 & 6.7 & 6 & 4.5 & 6 \\
3 & K0 & H.3 & 2.5 & 3.7 & 3 & 3 & 3 \\
4 & K0 & H.4 & 1 & 1.5 & 1 & 1 & 1 \\
5 & K0 & H.5 & 1 & 1 & 1 & 1 & 1 \\
6 & K20 & H.1 & 9 & 9 & 9 & 9 & 9 \\
7 & K20 & H.2 & 6 & 6.7 & 6 & 6 & 6 \\
8 & K20 & H.3 & 3 & 4.5 & 3 & 3.7 & 5.2 \\
9 & K20 & H.4 & 2 & 2.5 & 2 & 2 & 2.5 \\
10 & K20 & H.5 & 2 & 2 & 2 & 2 & 2 \\
11 & K40 & H.1 & 9 & 9 & 9 & 9 & 9 \\
12 & K40 & H.2 & 6.7 & 7.5 & 6 & 6.75 & 8.5 \\
13 & K40 & H.3 & 3 & 5.4 & 3.7 & 4.5 & 6 \\
14 & K40 & H.4 & 4 & 3.7 & 4 & 4.5 & 3
\end{tabular}


Table 1. Summary Score data observation of 5 parameters

\begin{tabular}{lllccccc}
\hline 15 & K40 & H.5 & 4 & 4 & 4 & 4 & 4.5 \\
16 & K60 & H.1 & 9 & 9 & 9 & 9 & 9 \\
17 & K60 & H.2 & 6 & 7.5 & 6.75 & 8.5 & 9 \\
18 & K60 & H.3 & 3.7 & 6 & 4.5 & 5.4 & 6 \\
19 & K60 & H.4 & 4.5 & 3.7 & 3 & 3 & 4.5 \\
20 & K60 & H.5 & 4 & 4 & 4 & 4.5 & 4 \\
21 & K80 & H.1 & 9 & 9 & 9 & 9 & 9 \\
22 & K80 & H.2 & 6 & 7.5 & 6 & 6.7 & 7.5 \\
23 & K80 & H.3 & 3 & 6 & 3.7 & 6 & 5.4 \\
24 & K80 & H.4 & 4.5 & 4.5 & 3 & 3.7 & 3 \\
25 & K80 & H.5 & 4 & 3.7 & 40 & 3 & 4.5 \\
\hline
\end{tabular}

The effect of guava leaf extract to mackerel fish preservation with parameter of eye is presented in Figure 1.

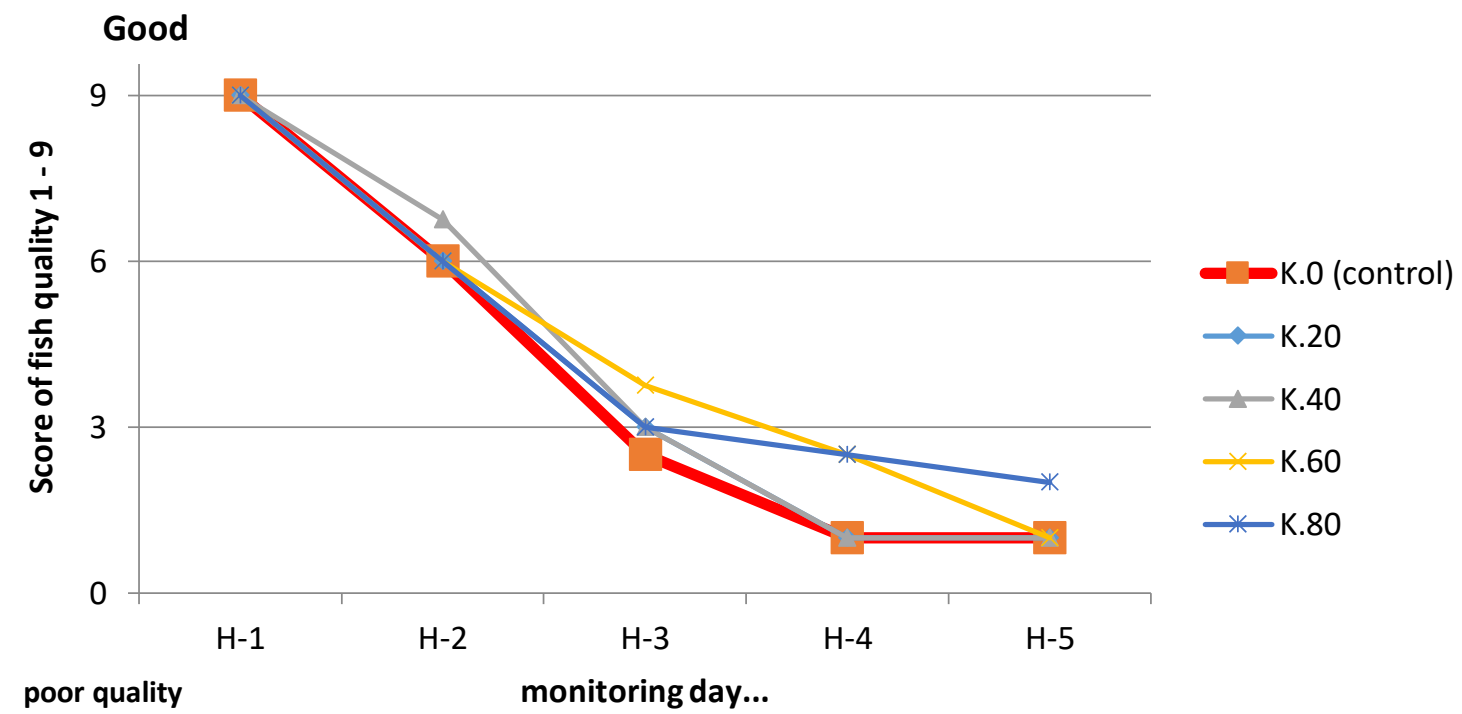

Figure 1. Fish quality based on eye

Guava leaf extract on concentration $60 \%$ and $80 \%$, in $4^{\text {th }}$ day preservation, the score of fish quality, still in score 3. On the other hand, the other treatments $(0 \%, 20 \%$ and $60 \%)$, the quality score of fish had been decreasing at 1 , that means the fish samples had been completely spoilage. The effect of guava leaf extract to mackerel fish preservation with parameter of gills is presented in Figure 2. 


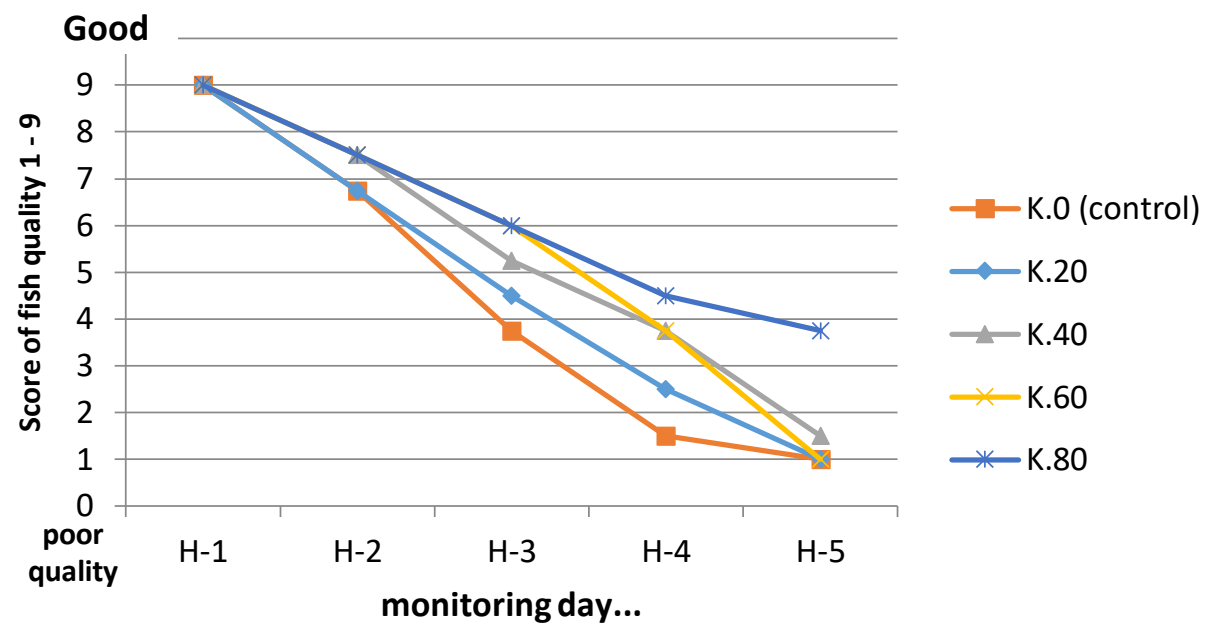

Figure 2. Fish quality based on gills

Figure 2 shows that common guava leaf extract on concentration 20,40 and $60 \%$, in $4^{\text {th }}$ day preservation, has score of fish quality 1 around 3. Treatment with concentration $80 \%$ in $4^{\text {th }}$ day has score 4 (the fish is still available to be consumed) and at $5^{\text {th }}$ day preservation has score 4 . At day 4 the control treatments $(0 \%)$, the quality score of fish had been decreasing at below score 2 , that means the fish samples had been spoilage. This results indicate that common guava leaf extract has a potency to be used for preservation of fish.

The effect of guava leaf extract to mackerel fish preservation with parameter of Aroma is presented in Figure 3.

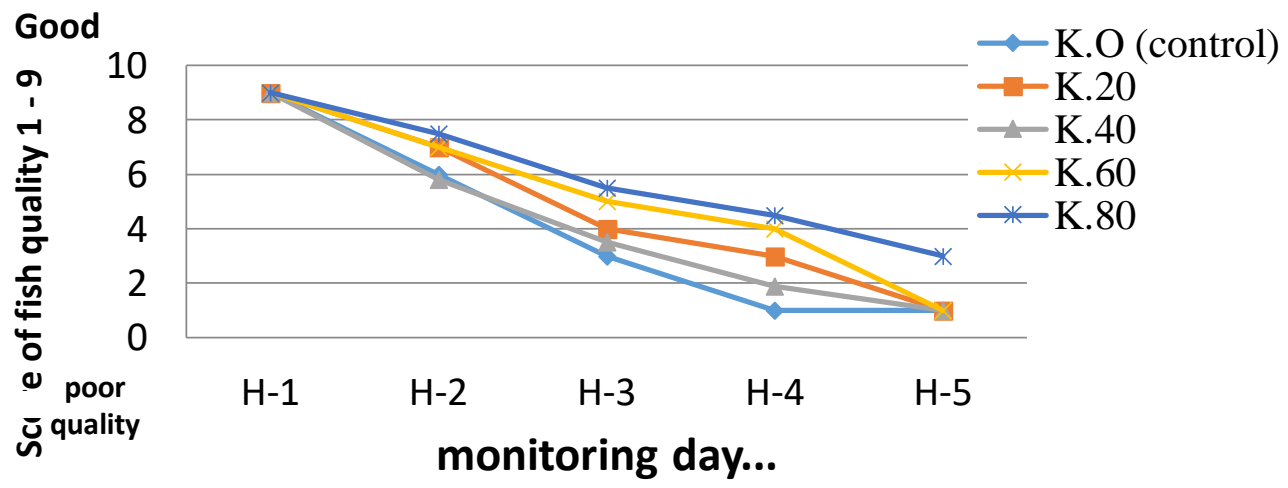

Figure 3. Fish quality based on odour

Graph 3 shows on $4^{\text {th }}$ days preservation, the quality score of fish with treatments, 20, 40, 60 and $80 \%$, all gave higher that score on control $(0 \%)$. Treatment with concentration $80 \%$ at $5^{\text {th }}$ day preservation has score 3 and the other treatments have been decreased on score 1.

The effect of guava leaf extract to mackerel fish preservation with parameter of texture is presented in Figure 4. 


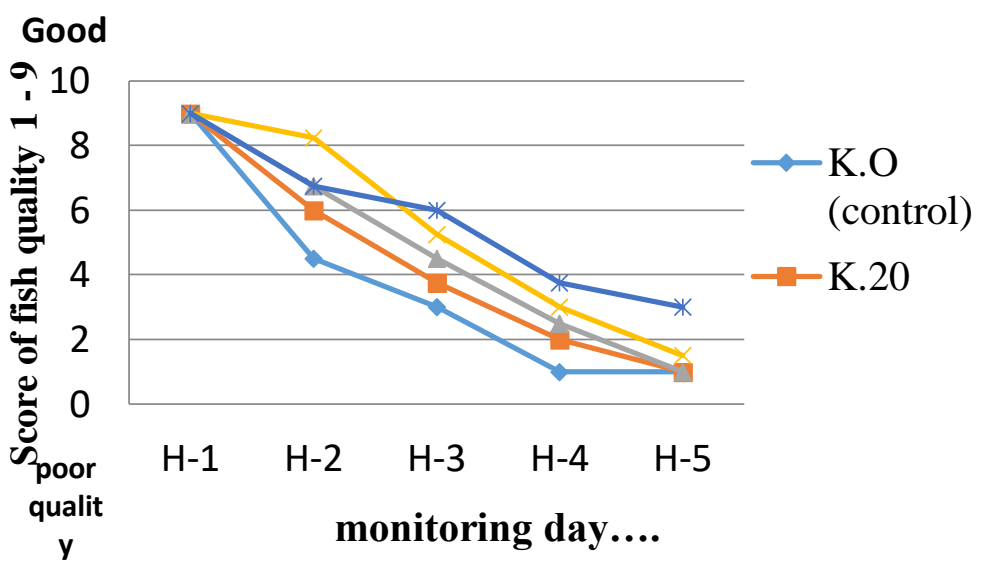

Figure 4. Fish quality on muscle texture

Figure 4 shows that common guava leaf extract on concentration 20,40 and $60 \%$, in $4^{\text {th }}$ day preservation, has score of fish quality on around 3. Treatment with concentration $80 \%$ in $4^{\text {th }}$ day has score 4 (the fish is still available to be consumed) and at $5^{\text {th }}$ day preservation has score 4 . On the other hand, the control treatments $(0 \%)$, the quality score of fish had been decreasing at 1 , that means the fish samples had been completely spoilage. Figure 4 indicate again, that common guava leaf extract potential to be used for fish preservation.

The effect of guava leaf extract to mackerel fish preservation with parameter of mucilage is presented in Figure 5.

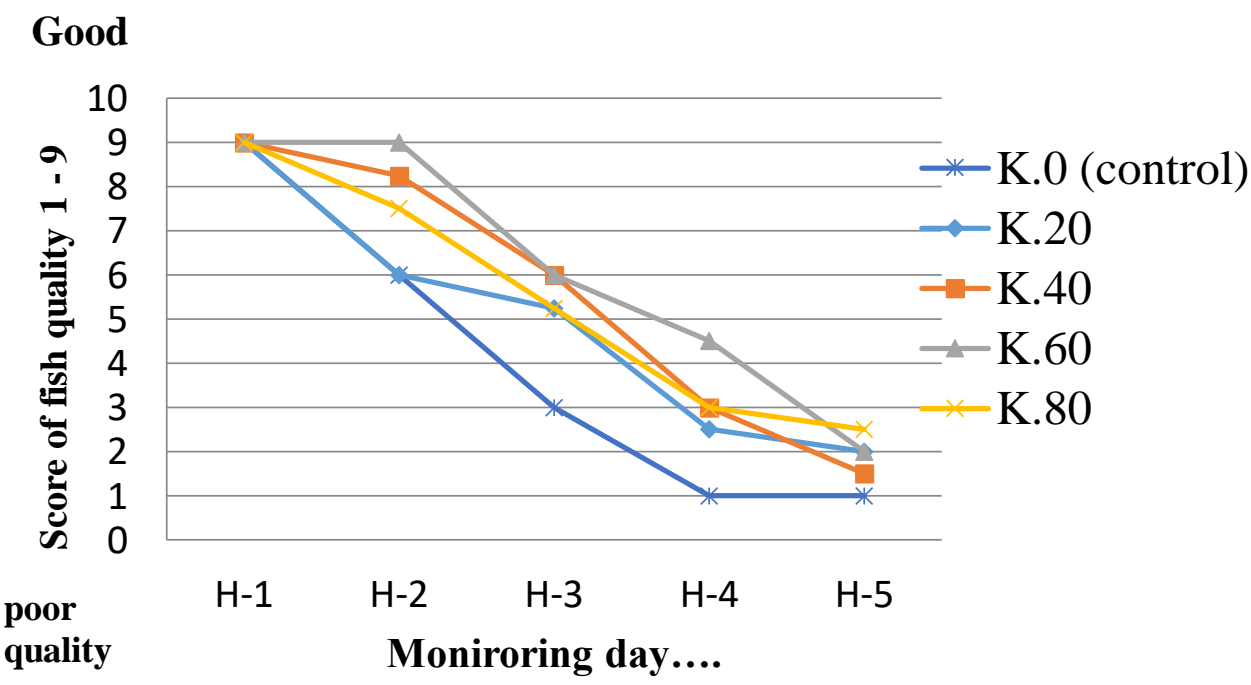

Figure 5. Fish quality on parameter : mucilage

Guava leaf extract on concentration $20,40,60$ and $60 \%$, at $4^{\text {th }}$ day preservation, has score quality on around 3. Treatment with concentration $80 \%$ in $3^{\text {rd }}, 4^{\text {th }}$ and $5^{\text {th }}$ day has score higher that score on control $(0 \%)$. The result showed that guava leaf extract has a potency to be used to preserve fish. 


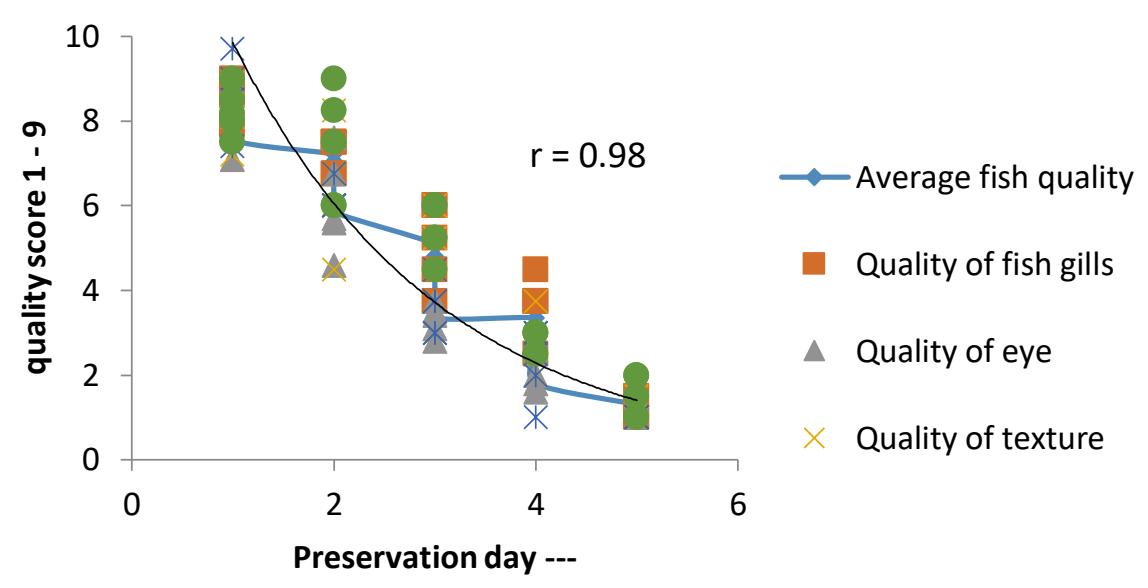

Figure 6. Fish quality on $1 \mathrm{~s} / \mathrm{d} 5$ days storage

Based on data on Figure 1, 2, 3, 4 and 5 was averaged, therefore, it will be able to see at Figure 6 showed prediction of $\mathrm{Y}=5.6-0.4003 \mathrm{X} 400+0.38 \mathrm{X} 40-0.4005 \mathrm{X} 3+0.408 \mathrm{X} 4-0.4006 \mathrm{X} 5$ in which $\mathrm{Xi}$ is the score of parameter $\mathrm{i}(\mathrm{X} 1=$ eye, $\mathrm{X} 2=$ gills, $\mathrm{X} 3=$ odour/aroma, $\mathrm{X} 4=$ texture and $\mathrm{X} 5=$ mucilage). The fish quality tend to decrease at day 1 st to 5 day after storage.

Figure 1 and 5 shows that (i) fish quality was decline and start to degenerate at $1^{\text {st }}$ day of storage, especially at control treatment ( no extract). Treatment at dosage $60 \%$ and $80 \%$, the fish quality were still relatively high over 3 days storage. Even though the fish samples have been started to spoilage, those fishes were still edible. At the same time, with the other treatment $(0,20$ and $40 \%)$, the fish samples get to spoil and no available to be consumed. However, at $5^{\text {th }}$ day storage, all samples at all treatments, the fishes have spoiled. Overall, it can be concluded that extract of guava leaves has low capacity as fish preservation.

\section{Conclusion}

4.1 Fish quality dropped drastically since 1st day preservation on control (without treatments).

4.2 Guava leaf extract on 60 and $80 \%$ concentration gave significantly effective to lengthen fish preservation within 3 days.

4.3 After 5 days of preservation, all fish on any treatments were spoiled and unavailable to be consumed.

4.4 Overall, guava leaf extract potential to be used as natural preservation particularly 


\section{Acknowledgement}

We would like to thank to Abdul Karim for technical assistance

\section{REFERENCES}

[1] Burhanuddin, S., Martosewojo S., Adrim, dan Hutomo M. Sumberdaya Ikan Kembung. Jakarta, Lembaga Oseanologi Nasional-LIPI. 1994

[2] Hermawan. Uji Aktifitas Ekstrak Daun Jambu Biji Sebagai Antimikroba Terhadap Bakteri Karies Streptococcus mutans Secara In Vitro. Skripsi, Malang Universitas Brawijaya. 2012.

[3] Cahyono, B. Sukses Budidaya Jambu Biji di Pekarangan dan Perkebunan. Yogyakarta, Lily Publisher. 2010.

[4] Gutiérrez, R.M., Mitchell, S., Solis, R.V.. "Psidium guajava: A review of its traditional uses, phytochemistry and pharmacology". Journal of Ethnopharmacology, 117: 1-27. doi:10.1016/j.jep.2008.01.025. 2008, PMID 18353572.

[5] Ashari, S. Hortikultura Aspek Budidaya. Universitas Indonesia Press.Jakarta. 2006.

[6] Rattanachaikunsopon, P and Phumkhachorn P. Bacteriostatic effect of flavonoids isolated from leaves of Psidium guajava on fish pathogens. Fitoterapia, 40007, volume 78, number 6, 1998.

[7] Heuzé, V., Tran G., Bastianelli D., Lebas F. Guava (Psidium guajava). Feedipedia, a programme by INRA, CIRAD, AFZ and FAO, 2017, https://www.feedipedia.org/node/111 Last updated on May 5, 2017, 10:59.

[8] Sudarsono, Gunawan, D., Wahyono, S., Donatus, I.A., Purnomo. Tumbuhan Obat II (Hasil Penelitian, Sifat-sifat dan Penggunaan). Yogyakarta, Pusat Studi Obat TradisionalUniversitas Gadjah Mada. Long-distance solo calls of white-handed gibbon males (Hylobates lar). American Journal of Physical Anthropology,44, 196-197. 2002.

[9] FAO Fact Sheet. Biological characteristics of tuna". Archived from the original, 2019, Retrieved 6 March 2012.

[10] Keay, J.N. Handling and processing mackerel Torry advisory note 66. 2001.

[11] Croker, R., Symonds The California mackerel fishery, Division of Fish and Game of California. pp. 9-10. 1933. 